\title{
Collaborative alignment of design partners: first step towards the definition of multiple design process models used by an automotive supplier according to specific carmakers
}

\author{
Rogerio Nakamura ${ }^{1}$, Henrique Rozenfeld ${ }^{2 *}$ \\ ${ }^{1} S E G$ Automotive Components Brazil Ltda., Itupeva, SP, Brasil \\ ${ }^{2}$ Departamento de Engenharia de Produção, Escola de Engenharia de São Carlos, Universidade de São Paulo - USP, São Carlos, SP, Brasil
}

\begin{abstract}
Each player in the automotive value chain usually has its own design process model. Suppliers must evaluate the process by eliminating, adjusting (crashing), or fast-tracking steps according to each demand of a specific project. Sometimes a carmaker involves a supplier too late in the overall design process. Consequently, suppliers must pass over some validation activities and accelerate others to keep pace with the carmaker. This research aims to create a supplier design process model aligned with a carmaker's, which can support the collaborative design and prevent future problems. Based on this experiment, the broader objective is to define a set of process models for any relationship with specific carmakers. The methodology adopted is insider action research carried out in a real environment. One of the researchers is an employee of the company, which provided many insights for this research. The results confirm the reduction of the design development effort measured in engineering hours and development costs. The development lead time was also reduced, but other practices such as joint meetings may have contributed to this reduction. These practices were deployed from the integrated and aligned collaborative process model.
\end{abstract}

Keywords: automotive industry, collaborative, product development management, product development process.

\section{Introduction}

Collaborative product design has been known since the 1980s, as have its benefits, which include shorter development lead time, increased performance (Brown \& Eisenhardt, 1995, p. 371; Clark, 1989, p. 1260; Clark \& Fujimoto, 1989, p. 30-34), reduction of potential project delays (Hartley et al., 1997, p. 68) and less complicated incorporation of new technologies (Littler et al., 1995, p. 22; Ragatz et al., 1997, p. 197).

Over the last decade (2000s), the agile approach has enabled the addition of iterative and frequent feedback between customer and supplier, placing them face to face (Conforto et al., 2015; Sutherland, 2014) in the search for greater flexibility. This means that the later the product can be changed without any substantial impact during its development the greater the flexibility of the process (Smith, 2007, p. 37).

In the automotive industry, the supplier's engagement in the conceptual design phase of the vehicle (Early Supplier Involvement, ESI) plays a key role in the results of the collaborative partnership (Binder et al., 2008; Petersen et al., 2005).

The ESI process is normally driven by automakers' strategies such as "follow design" and "follow source." The follow design strategy establishes a worldwide design standard aimed at preserving global quality. Follow source focuses on optimizing development costs to define a key supplier for worldwide development involving many locally installed manufacturing plants. However, these global strategies have been unsuccessful in some regions for specific reasons, e.g., production capability, absence of the same supplier at all the manufacturing locations, economics, local legislation, conditions of usage, etc.(Humphrey, 2003). This means it is sometimes not possible to work with the predefined worldwide preferred supplier. Therefore, an automaker may select a non-preferred supplier later. Since the supplier's involvement in the collaborative process comes too late, his competitive advantage is reduced (Oh \& Rhee, 2010).

When a carmaker involves its suppliers too late in the overall design process, the latter must pass over some validation activities defined in their design process models and accelerate others in order to launch the system under their responsibility on time. This requires the definition of a collaborative risk management plan.

Received: August 28, 2020. Accepted: November 17, 2021.

*Corresponding author: Henrique Rozenfeld. E-mail: roz@usp.br 
The supplier tries to minimize problems resulting from his late involvement by synchronizing information which is spread across different models, views and processes of both organizations (carmaker and supplier), jeopardizing the managerial decision-making capability (Browning, 2009). One way of doing this is by aligning the carmaker's and supplier's design process models (Evans \& Jukes, 2000; Kim et al., 2012).

Each player in the automotive value chain may define its own design process model, which can be adapted depending on the type of project, such as incremental, new generation, new platform, breakthrough development (Du Preez et al., 2009). First-tier suppliers must evaluate the process by eliminating, adjusting (crashing), or fasttracking steps according to each requirement of a specific development project, such as short time-to-market, late changes, introduction of new technology, etc. (Clift \& Vandenbosch, 1999). The design processes of first-tier suppliers must comply with the carmaker's design process, at least in terms of the main milestones or gates. But even if suppliers are co-developers or strategic partners, they follow different process models with some integration points (Evans \& Jukes, 2000; Martens, 2008).

Some automakers demand that the design process of their suppliers be based on the APQP (advanced product quality planning) of IATF 16949 (Attia \& Rathod, 2005). APQP is a description of the main possible phases, deliverables and methods/tools that should be considered in order to define a common reference in the relationship between a customer (carmaker) and a supplier in the automotive industry. This standard is aimed at integrating and facilitating collaborative work between players. However, APQP is only a high-level description of the design process. This level of description ensures flexibility of the supplier's design process. Any organization has the flexibility required to define its own design process according to its particularities while simultaneously complying with APQP (Chrysler Corporation et al., 2008).

The design process of each organization (carmaker or supplier) has the one-size-fits-all mindset (Shenhar, 2001), although it is adaptable to the complexity of the development. The supplier's design process model does not fit the carmaker's process, but it is assumed that the tacit knowledge of the project manager can solve the gap during the adaptation and instantiation of the design process into a project plan. This, in fact, increases the uncertainties that lead to problems during the planning and execution of the project.

This paper describes a solution for the aforementioned difficulties adopted by one first-tier supplier of the automotive industry. The aim is to have a "set" of design process models that share a common content (based on process building blocks) instead of working with a single "adaptable" design process model. There is one model for each customer (carmaker). The goal of this paper is to present the creation and application of one of these models. It is a design process model integrated and aligned with a carmaker's design process, which can be adapted according to types of projects. Thus, the instantiation and adaptation of the supplier design process to the carmaker's process would decrease the impact of uncertainties and increase the competitive advantage of collaborative design.

The paper is divided into four sections: the first one presents a review of collaborative design in the automotive industry, as well as automotive design process models and an adaptive project plan process. Section two presents the research methodology, describing the research approach and the activities carried out. The third section describes the results and analysis of the development and application of the new process model created specifically to support a collaborative design with a customer (carmaker). The last section discusses the lessons learned and outlines the ongoing deployment of design process models for other customers.

\section{Literature review}

Most of the references of collaborative design processes state that the concrete benefits of this strategy are cost reduction; time-to-market reduction (mainly due to the decrease in engineering hours); and improved quality performance (Binder et al., 2008; Oh \& Rhee, 2010; Petersen et al., 2005; Zendoia et al., 2013). These benefits will be evaluated in this research.

Terms such as alignment, integration, sharing and adaptation are common keywords employed in collaborative environments (Amaral et al., 2011; Amin et al., 2014; Highsmith, 2012; Kim et al., 2012).

\subsection{Collaborative design in the automotive industry}

The most well known definition of collaborative design in the automotive industry describes the supplier's direct involvement in vehicle development, starting in the early stages of the automaker's design process (Oh \& Rhee, 2008, 2010). This collaboration may range from an ordinary inquiry about design ideas to the development of the entire system by the supplier (Petersen et al., 2005).

Collaboration is also defined as the evolution of the regular relationship between the carmaker and supplier (Petison \& Johri, 2008), which enables the achievement of the competitive advantages of sharing processes, resources, know-how and lesson learning (Peters et al., 2010). Collaboration is driven to think "strategically in 
terms of the whole life cycle costs of a product (including warranty cost) rather than just the short-term R\&D costs upfront" (Binder et al., 2008, p. 325).

A collaborative environment depends on the following factors: contractual mode, evolution of collaborative process and type of collaboration (Binder et al., 2008; Kim et al., 2012; Petison \& Johri, 2008).

Contractual mode refers either to a strategic partnership for long-term relationship, known as relational mode or to a contract based solely on price and volume. A hybrid mode that combines the contractual and relational modes is also possible (Binder et al., 2008).

The contract supports the development of the collaboration process, which is the second factor to elicit collaboration. An automaker-supplier relationship involves four stages of collaboration, as described by Petison and Johri (Petison \& Johri, 2008). In the first stage (search for high potential suppliers), a carmaker screens suppliers in terms of quality and schedule. Then, in the second stage (developing high potential suppliers), the carmaker works with the supplier to enhance the latter's technical capability and operations management skills in order to improve quality and productivity and to reduce cost. In the last two stages (learning and synergy), automaker and supplier establish a long-term partnership focusing on a product's life-cycle costs.

As for the third factor (type of collaboration), improvements are needed in "vertical collaboration" (carmaker and his supply chain) and in "horizontal collaboration," which is a process of interdepartmental collaboration within the company through the "rearrangement or integration of processes" (Kim et al., 2012).

As a synthesis of several collaborative attributes emerged from the analyzed publications, this paper suggests these attributes should be distributed among the stages of collaboration and different contractual modes (see Figure 1).

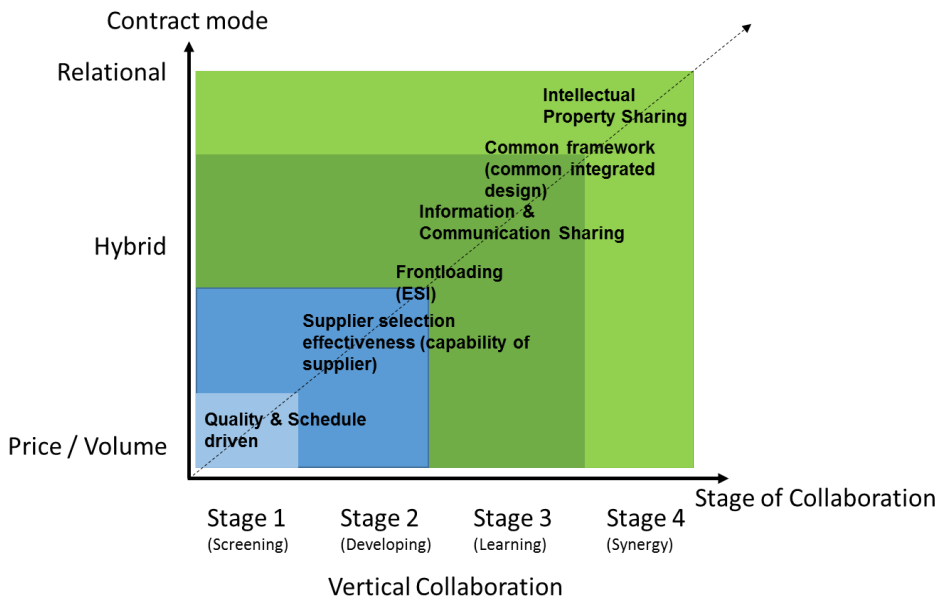

Figure 1. Distribution of the collaborative attributes among contract modes versus stages of collaboration. Source: developed by the author.

To implement the collaborative environment as established by (Kim et al., 2012) and (Guerrini \& Pellegrinotti, 2015), the focus should concentrate on: a repository for design tools and methods for modeling the description of a common process; a common framework for sharing information; and a process model to share intellectual property and knowledge and to ensure collaboration.

\subsection{Collaborative reference models or design process models in the automotive industry}

Some authors use the term reference model (Camarinha-Matos \& Afsarmanesh, 2006, pp. 2457-2458; Salminen \& Pillai, 2005, p. 7), design process model (Guzzo, 2016) to describe the same content: a representation of the design process that can support the definition of a development project plan. There are also different names according to the level of abstraction, such as generic reference model, specific reference model (Browning, 2009, p. 75; Sommer et al., 2014, p. 184), instantiation in a project (design process model of a project) or operation (representation activities) (Guzzo, 2016).

In this paper, the generic reference model pertains to the Advanced Quality Product Planning \& Control Plan (APQP) of ISO/TS 16949:2009, currently in transition to IATF 16949:2016. Some derivations of the ISO/TS 16949 are represented by standards in different countries, such as that of the German Verband der Automobilindustrie, VDA6.3, the French Evaluation d'aptitude sur la qualité pour les fournisseur, EAQF, and others.

The specific reference models represent the design process of a specific organization derived from the generic reference model (Gericke \& Moser, 2012, p. 111; Rozenfeld et al., 2006, p. 93). Most of these models described 
in the literature are represented through a phased process for the automotive segment, as in (Lehmann \& Grzegorski, 2008, pp. 84; 132) and (Nakamura et al., 2016, p. 2). As can be seen, all design processes are represented similarly (in phases or stages), albeit with different abbreviations and terminologies that are nevertheless in compliance with the same APQP process (see Figure 2).

In dealing with different design process models from several carmakers, each supplier must support the collaborative process by aligning those specific models with its own model, according to the following steps(Evans \& Jukes, 2000, pp. 982-985):

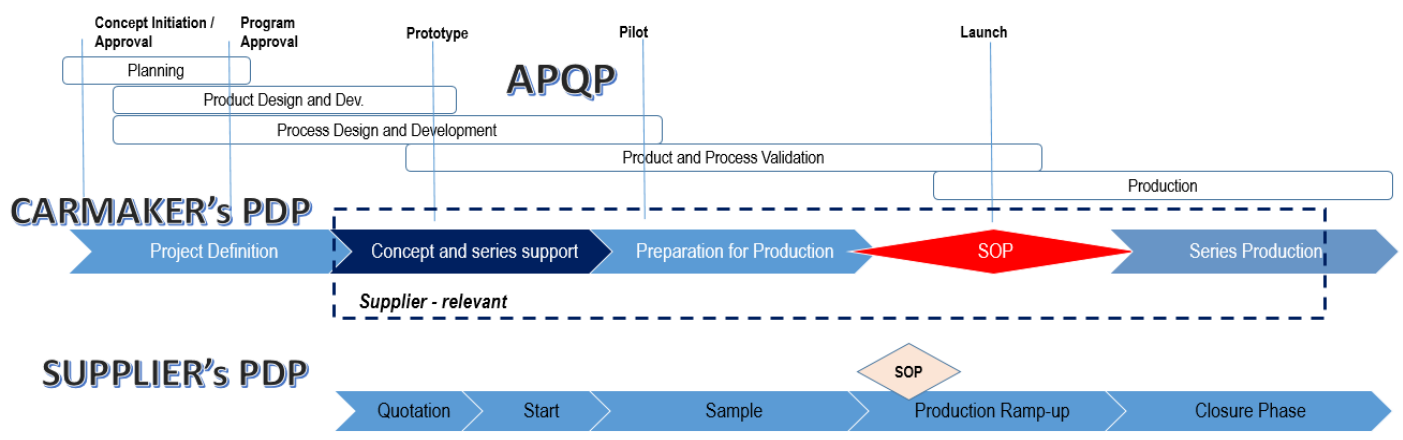

Figure 2. PDPs from carmaker and supplier. Source: adapted from NAKAMURA et al., 2016 and from Chrysler et al., 2008.

- Standardize the value-added contents in each design process;

- Be knowledgeable about each phase of the carmaker's design process;

- Align the phases and activities of the design process;

- Reduce any gaps between carmaker and supplier in terms of collaboration.

Other authors use the Design Chain Operations Reference Model (DCOR) to cover the four steps mentioned above in the Korean automotive and motorcycle markets (Kim et al., 2012; Wu et al., 2007 and Choi et al., 2005). In addition, they intend to develop a common framework for vertical collaboration; and standardize terminologies, processes, and services. This leads to new challenges for process modeling, such as: integrating different users' visions, decreasing complexities in information exchange, and making the communication process transparent (Amaral, 2002; Levardy \& Browning, 2009).

Although (Kim et al., 2012; Wu et al., 2007) want to synchronize the processes by integrating data and establishing a common communication protocol to avoid misunderstandings through a common reference model, their proposal faces the uncertainties that come with the One Size Fits All mindset.

Thus, the contingency environment under agile and flexible product development (design) stated in (Browning \& Ramasesh, 2015; Highsmith, 2012; Smith, 2007) should consider the theory of adaptive project management.

\subsection{Adaptive project management}

Evans \& Jukes, 2000 recommend the use of a blank wall chart to synchronize the design processes of the carmaker and supplier (see Figure 3).

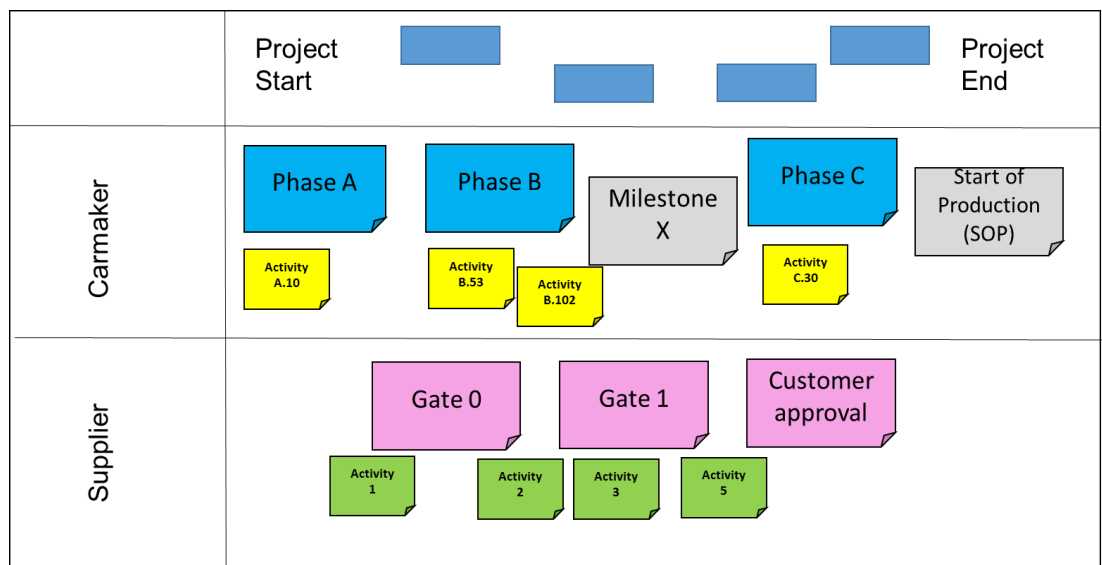

Figure 3. PDP synchronization wall chart. Source: adapted from Evans \& Jukes, 2000, p. 985-986. 
The two teams describe each design process in a row, using sticky notes and comparing them. The upper side of the chart is the result of synchronization, whereby they are combined in an initial project plan (Evans \& Jukes, 2000).

According to Browning (2010, p. 316), the project can be represented by several views, as illustrated in Figure 3, but may still not answer following questions: "What if the view used by a manager does not contain the necessary and sufficient information to support a particular decision? Or, what if the essential information to support a managerial decision is buried in irrelevant information?"

A project management life cycle is characterized by uncertainties and a dynamic environment, which drive project managers to choose one of the following methodologies for scheduling according to the type of project: PERT/CPM, schedule risk analysis, resource constrained scheduling, or critical chain/buffer management (Vanhoucke, 2012).

During the project, its scheduling and information "commonly use a variety of process models to plan and coordinate work, including process flowcharts, Gantt charts, work breakdown structures (WBSs), and formal procedures," which are distributed among the departments of the organizations involved (Browning, 2009, p. 70).

"Rather than pre-specifying which activities will be done and when, i.e., instead of dictating a specific project schedule a priori, it should provide a "primordial soup" of activities and rules, through which the activities can self-organize and adapt to the changing state of a project" (Levardy \& Browning, 2009, p. 601), according to timely circumstances.

Working with a focus of flexibility and adaptability depends on the factors of uncertainty and complexity of each project. Therefore, defining the classification of the project based on the NTCP model (novelty, technology, complexity and pace) gives the project team a chance to adapt it during the planning, monitoring and execution (Shenhar \& Dvir, 2007).

\section{Research methodology}

This research is based on the hypothetic-deductive paradigm (Echeveste et al., 2007, p. 249). The hypothesis in this research is "if the supplier's design process model is aligned with the customer's design process, then this practice can improve the collaborative design between the two organizations." Until such time as the practice is adopted by many organizations, however, the hypothetico-deductive paradigm states that while a theory cannot be proven to be true, it can be proven false with a contradictory observation (Helfenbein \& DeSalle, 2005). Therefore, this research adopts the action research approach. An action towards the implementation of the hypothesis is an attempt to falsify it.

The researcher, who belongs to the supplier organization and contributes to the scope of the research, played a key role into this project. Thus, the authors chose the insider action research methodology as the most suitable one. This methodology is a variation of the action research methodology of the operations management domain (Brones, 2015; Coghlan, 2007; Coughlan \& Coghlan, 2002, 2009).

In action research, the researcher not only interacts in the research project but is also part of the action. His role is to synthesize the action, turning it into knowledge or theory through the action itself (Coughlan \& Coghlan, 2002).

Normally, the role of the action researcher is that of an outsider "acting" inside the project. Insider action research, instead, involves intimate knowledge of the organization, its culture and its processes, which are often the subject of the research. Role duality confronts political interest and misjudgment, which is the main criticism about the performance of insider action research (Coghlan, 2007; Holian \& Coghlan, 2013).

The research adopted the cycle proposed by Coghlan and Brannick, cited by (Coughlan \& Coghlan, 2009). The action research cycle comprises a context and purpose step and four basic iterative steps: diagnosing, planning action, taking action and evaluating action.

As stated at Rowley (2003), action research projects are presented in two cycles operating in parallel. One as stated above, and the second one is a reflection cycle, which embed the learning processes of the action research cycle before of the next cycle. This reflection raises a learning about the learning (meta learning), involving at least a process of experiencing, reflecting and interpreting.

This paper describes a solution for the difficulties mentioned above adopted by one first-tier automotive industry supplier. The aim is to have a "set" of design process models that share a common content (based on process building blocks) instead of working with a single "adaptable" design process model. Thus, there is one model for each customer (carmaker). The goal of this paper is to present the creation and application of one of these models. It is a design process model integrated and aligned with a carmaker's design process, which can be adapted according to the types of projects. Thus, the instantiation and adaptation of the supplier design process 
to the carmaker's process would decrease the impact of uncertainties and increase the competitive advantage of collaborative design.

\subsection{Context and purpose}

In this step, the context of the research, business description and research environment are created based on the following questions: What is the reason for the research? and What are the reasons for the action?

The process for collecting data is also considered a critical item for meta-learning, which is learning to learn. For this research, we consider journal keeping, and structured and informal interviews based on a script as an inquiry process (Coughlan \& Coghlan, 2009, p. 256).

There was a total of 15 interviewees from the carmaker and supplier, who were also involved with the overall project of which this action research is a part. The departments involved at the carmaker were New Program Area; Supplier Quality Assurance; and Engineering, while those at the supplier were Project Management Office; Continuous Improvement; Methods \& Processes and Engineering.

In order to judge the consistency of the action research steps, a reference design project and a pilot design project were chosen for purposes of comparison and validation.

\subsection{Diagnosing}

The activities planned for this step were:

- Discover the potential for improvement of the supplier's design process model in order to align it with the carmaker's design process.

- Establish required information and data source to define metrics for measuring the improvements. All the information thus garnered will be used as baseline for the pilot design project.

\subsection{Planning action}

Based on the diagnosis, a plan was drawn up for the last two stages of the collaboration mode (See Figure 1). Concurrent to the introduction of new practices to solve most problems indicated by the diagnosis, the focus of this publication was planned as follows:

- Create a new design process model and corresponding instantiation in a project, linking together the role, responsibility, and due date for each task.

- Analyze the results of the tasks and correlate them with findings from the literature review.

- Measure the value of defined metrics.

- Validate the results of the tasks.

\subsection{Taking action}

The pilot project was carried out based on the initial plan created during the preceding phase. However, this plan had to be updated during the development of the new product. The following activities were carried out:

- Jointly (carmaker \& supplier) verify the feasibility of each activity, adjusting it if necessary.

- Record the results, unexpected effects and interventions.

\subsection{Evaluating action}

After the first cycle, the achievements should be confirmed by comparing them to the expected results. Based on the results, the authors analyzed these achievements using the technique known as "logic models" proposed by (Yin, 2003, p. 109), which "consists of matching empirically observed events to theoretical events." The metrics defined to measure the success of the application were evaluated.

\subsection{Reflection cycle (Meta Learning)}

Although the product design details or the technological solution of the design influences the instantiation of the design process model, as several detailed characteristics as novelty, technology, complexity, pace, capabilities, and others, the focus of this analysis is based on the effects of these parameters from the model, not the details, creating conditions for conceptualize the answers for research questions (see Planning action).

The scope of this paper covers only one action research cycle, i.e., one development aimed at attempting to disprove the hypothesis. Reducing the limitation in not using a spiral of action research interventions (Rowley, 2003), those parameters' effects create conditions for setting-up the configuration of the action-research next steps, as well as further factors which could distort results.

\section{Results and analysis}

This action research project was included in a program headed by the carmaker, which was aimed at strengthening the carmaker's market position in South America, especially in Brazil, using its first-tier suppliers 
as strategic partners to leverage the competitive capability of its business. The program lasted almost three years and was kicked off using the supplier organization of the insider action research. The action research project was in line with the supplier organization strategy, which aimed to improve the alignment of the supplier's process with that of the customer.

The two organizations involved in the action research project are multinational companies whose headquarters are in Europe. They are often ranked among the top original equipment manufacturers (OEMs) and auto parts suppliers. They have a global presence through their subsidiaries and regional companies in several countries. The research was driven by the supplier's point of view because the insider action research belonged to the supplier organization.

\subsection{Context and purpose}

The contractual mode of most of the projects involving the carmaker and supplier of this action research project is based on price and volume. As can be seen in Figure 1, their relationship is located between the second (developing) and third (learning) stages.

The carmaker's representatives of supplier quality assurance, engineering, purchasing and logistics have constant and free access to the supplier's project manager.

A project manager drives the supplier's project team, which is a multifunctional team. Each project member belongs to a functional department, part of a balanced matrix organization. A comparison of the degree of horizontal collaboration at the carmaker and supplier indicates that the latter shows greater interdepartmental integration with respect to the project's data synchronization.

To align the carmaker's design process models with those of the supplier, the vehicle's project milestones (green diamonds) must be synchronized with the supplier's gate reviews (white diamonds), as illustrated in Figure 4. The development of the project was planned and all the activities were scheduled based on this alignment. Usually, the supplier's project manager does this alignment himself by adjusting the suppliers' design process model to the main due dates of the events pertaining to the vehicle. The project manager has neither references nor guidelines that he can rely on.

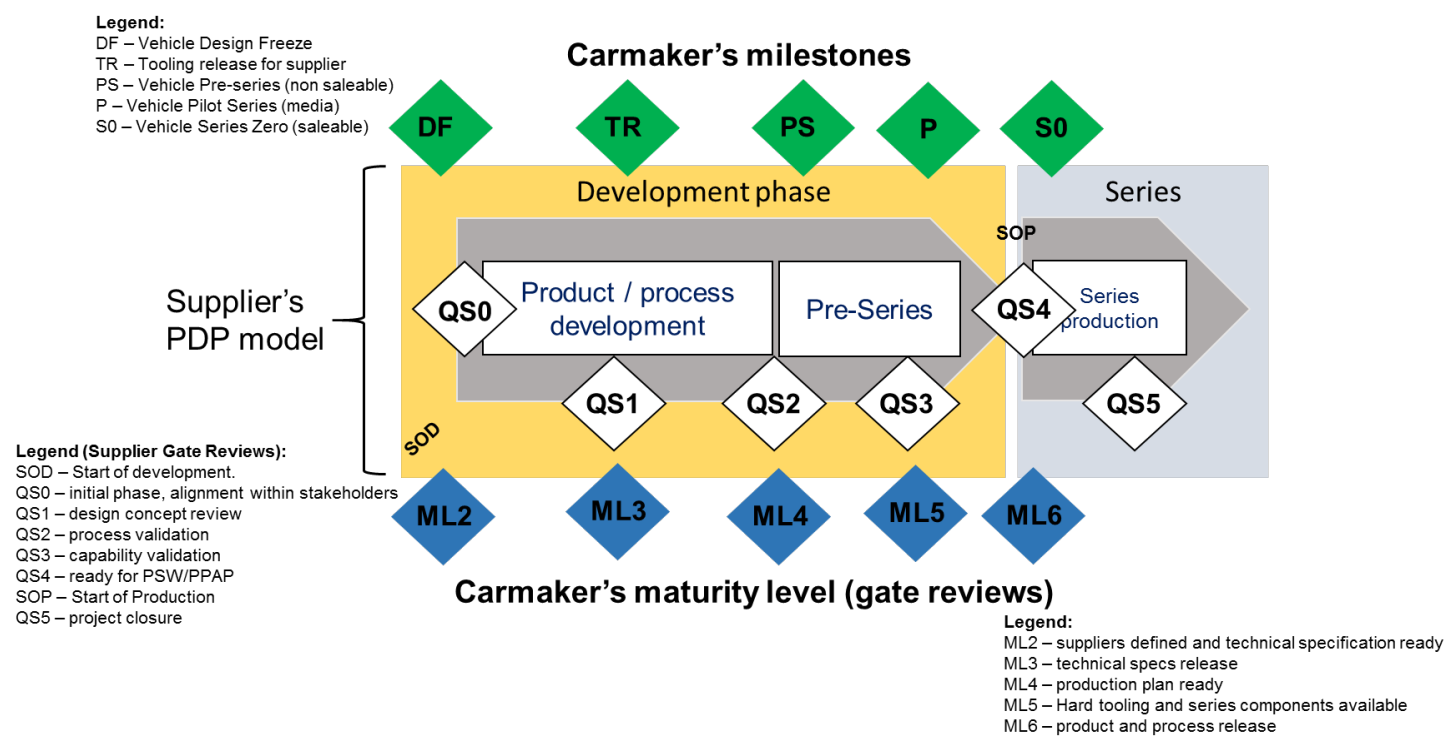

Figure 4. Alignment of the carmaker's PDP model to that of the supplier. Source: developed by the author.

In addition, the carmaker's supplier quality assurance department assesses the supplier's project through a gate review questionnaire (maturity level 2-6), which is quite similar to the supplier's gate review (QS0-5). Both are based on VDA's maturity level questionnaire.

During the context step of the action research cycle, an interview was held to confirm the following major problems detected in past projects:

1. Lack of a repository of design process models to use as reference for alignment between the carmaker's and supplier's new product development;

2. Low level of confidence about deliverables commitments agreed to at the start of the projects;

3. Non-integrated risk management;

4. Non-synchronized key information about the projects, which are spread among different departments. 
Both organizations decided to mitigate or even eliminate these problems using new design management practices, which include the definition of a common design process model (scope of this publication) in a new development project, called a "pilot project." In order to measure the improvements, they decided to compare the indicators of the pilot project with indicator of a similar project with analogous problems which run in the past. This former project is called in this publication as "reference project" (see Figure 5).

\section{Reference project}

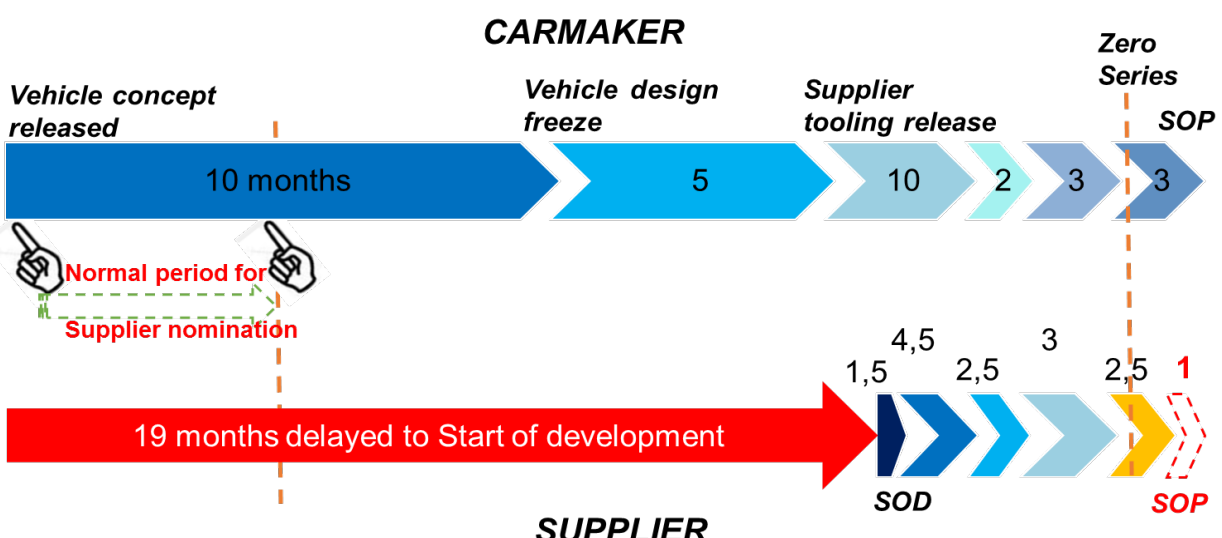

Figure 5. Reference project for the action research project. Source: developed by the author.

\subsection{Diagnosing}

In the preceding six years, the supplier organization recorded the project effort, in terms of working hours per type of project and per customer. It was found that, for the same type of project, there was a very significant variation in the efforts distributed (working hours) among the supplier's design process phases, as a function of different customers (Figure 6). However, the distribution of efforts dedicated to similar projects for the same customer varied only slightly.

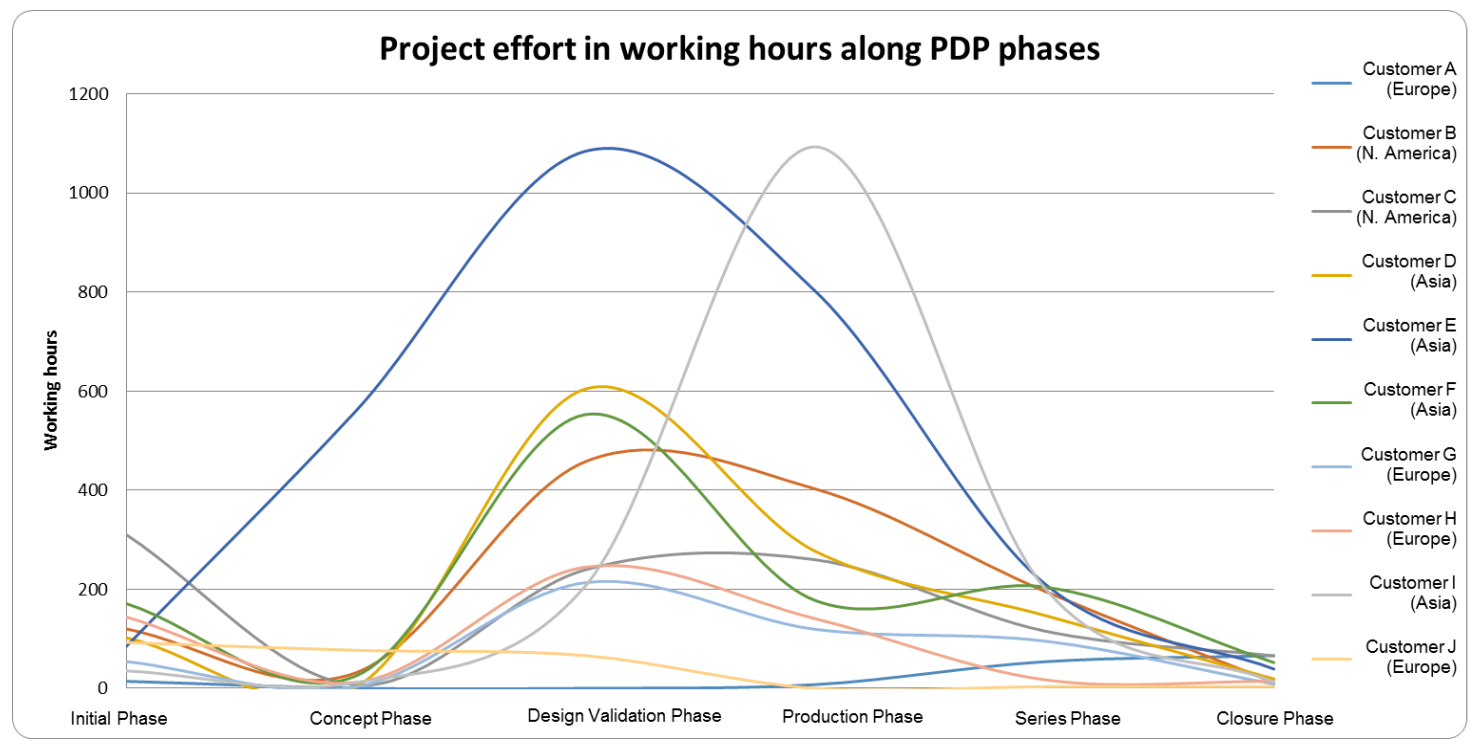

Figure 6. Distribution efforts, in working hours, throughout supplier's PDP phases. Source: developed by the author.

According to the aforementioned distribution, the supplier organization redirected its strategy to improve the effectiveness of design process performance. This was the starting point of the proposal of this article. It was decided to improve the flexibility of the design process model according to a project classification and to the operational particularities of each customer (carmaker). Taking the opportunity represented by the carmaker's program, the supplier organization put into practice this strategy, and the author of this paper used it to deploy this action research. 
Following the methodology described earlier herein, all the reference data were collected using the reference project. These data were compared with the results collected in the pilot project and for the purpose of this action research.

In addition to the type (classification) of reference project based on the NTCP model, Table 1 describes the data recorded during the adjustment of the supplier's PDP model to that of the carmaker.

The project manager and project team members used the approach described by (Evans \& Jukes, 2000) (Figure 3), identifying the sources of uncertainty (deviations, threats and opportunities) through three swimlane diagrams posted on a wall: two representing the actual supplier and carmaker design process model and the upper lane representing the project plan that would be the basis for the future specific design process model of the supplier for this type of project and this customer.

Table 1. Supplier PDP adjustment to the carmaker's events due to the 19-month delay of the reference project.

\begin{tabular}{ll}
\hline \multicolumn{1}{c}{ Work package adjustment } & \multicolumn{1}{c}{ Impact } \\
\hline $\begin{array}{l}\text { Anticipate the component design freeze before completing the } \\
\text { design validation test. }\end{array}$ & $\begin{array}{l}\text { Comply with the vehicle event, but with a functional design } \\
\text { risk. }\end{array}$ \\
$\begin{array}{l}\text { Release the order for hard tooling before completing the design } \\
\text { validation test. }\end{array}$ & $\begin{array}{l}\text { Comply with the vehicle event, although any fault revealed } \\
\text { during testing would affect tooling rework (time and cost). }\end{array}$ \\
$\begin{array}{l}\text { Adapt final assembly line in parallel with the development of } \\
\text { the design concept. }\end{array}$ & $\begin{array}{l}\text { Comply with the vehicle event, although any design rework } \\
\text { would affect assembly line rework. }\end{array}$ \\
$\begin{array}{l}\text { Start sourcing parts in parallel with the development of the } \\
\text { design concept. }\end{array}$ & $\begin{array}{l}\text { Comply with the vehicle event, although any design rework } \\
\text { would affect rework at the supplier. }\end{array}$ \\
Shorten the sourcing process period. & $\begin{array}{l}\text { Comply with the vehicle event, although supplier capability } \\
\text { could jeopardize the project. }\end{array}$ \\
\hline
\end{tabular}

Table 2 describes the uncertainties and corresponding impacts. Based on this information, the project team identified and marked the work packages and events that should be achieved or disregarded, and crashed or fast-tracked.

Table 2. Uncertainties of the reference project.

\begin{tabular}{|c|c|}
\hline Uncertainties & Impacts \\
\hline Technical Specifications incomplete in the quotation and up to QS1 & Change of scope, components, and tooling. \\
\hline Several customers' interfaces. & $\begin{array}{l}\text { Lack of synchronization and confidence in the key project } \\
\text { information. }\end{array}$ \\
\hline $\begin{array}{l}\text { Affected stakeholders not attending the kick-off meeting held } \\
\text { by the carmaker. }\end{array}$ & $\begin{array}{l}\text { Lack of commitment to meet the vehicle events and poor risk } \\
\text { identification. }\end{array}$ \\
\hline Delay in the selection of the supplier. & $\begin{array}{l}\text { Affected time, scheduling and achievement of the vehicle } \\
\text { events. }\end{array}$ \\
\hline Some maturity level reviews (ML2-6) not done. & Finding solutions for deviations took a long time. \\
\hline Late changes in specifications and requirements by the carmaker. & Affected the reliability of the design and schedule. \\
\hline
\end{tabular}

Based on the theoretical knowledge garnered from the literature review, the expectations of all stakeholders were aligned to drive the establishment of the actions aimed at improving the current situation (next section).

As mentioned earlier, the data collected from the reference project should validate the reduction of pilot project working hours (productivity), costs and improvement of quality (reduce quality issues at launch, such as 0 mileage failures). Thus, the supplier organization recorded the working hours planned at the beginning and the hours actually spent on the project, and also the fulfillment of the planned work packages and unexpected deviations.

In this diagnostic phase of the project, an analysis was made of the board adopted by the supplier as a visual management tool, which the project teams employ to monitor the progress of all ongoing projects. The post it notes represent the main work packages. This was considered a good practice and was used by this action research to monitor the plan (next section).

\subsection{Planning action}

Following the methodology, a project charter and a project management plan were outlined to describe the project plan, contracting (roles \& responsibilities), and activities sequencing (scheduling) to be monitored on the project board control. To validate the results of the planned tasks, the authors formulated a system to evaluate the action research model, as illustrated in Figure 7. 


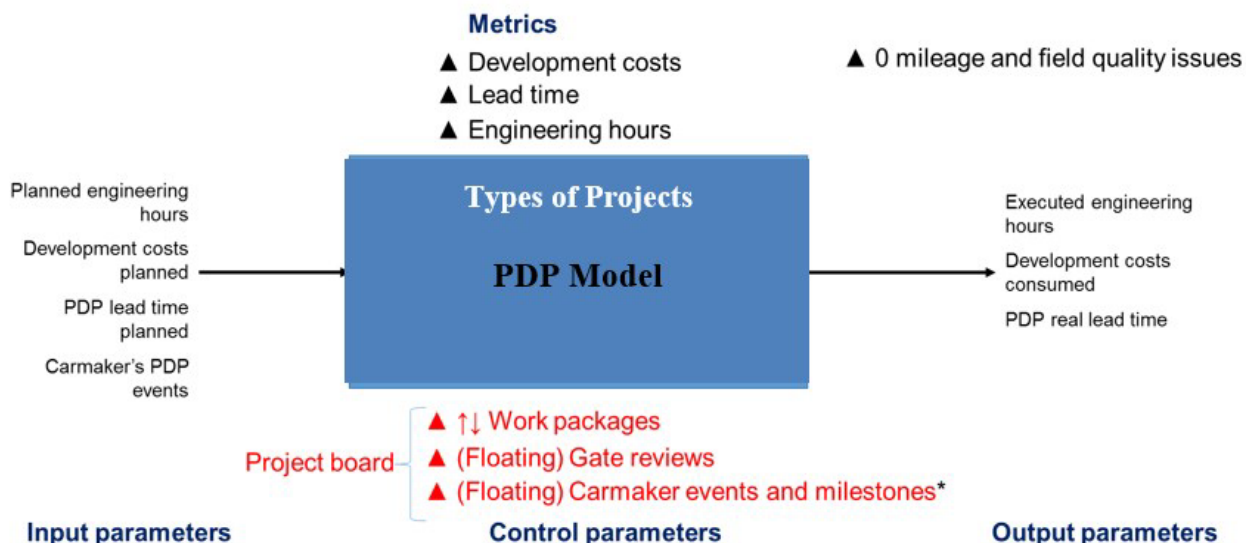

* Valid for pilot project assessment

Figure 7. Action research evaluation system. Source: developed by the author.

In order to deploy the key metrics to measure the results of the action research, the authors employed logical thinking to plan the action research, as described in Table 3.

Table 3. Logical thinking employed to plan the action research.

\begin{tabular}{|c|c|c|c|c|}
\hline Research question & $\begin{array}{l}\text { How? Foster and } \\
\text { Implement }\end{array}$ & Expected benefits? & Factors & $\begin{array}{c}\text { Validate } \\
\text { (+ metrics) }\end{array}$ \\
\hline \multirow{3}{*}{$\begin{array}{l}\text { How can the process of } \\
\text { PDP adaptation and } \\
\text { instantiation of each } \\
\text { supplier's project to the } \\
\text { carmaker's project be } \\
\text { easier and faster to be } \\
\text { done? }\end{array}$} & $\begin{array}{l}\text { Collaborative Product } \\
\text { Development Process: } \\
\text { - Collaboration in the } \\
\text { automotive PDP; } \\
\text { - Characterization of } \\
\text { the collaborative } \\
\text { PDP; }\end{array}$ & $\begin{array}{l}\text { - Reduced } \\
\text { engineering hours } \\
\text { and lead time; } \\
\text { Financial benefits } \\
\text { (profit, return on } \\
\text { investment); } \\
\text { - Product quality } \\
\text { improvement; } \\
\text { - Cost reduction; }\end{array}$ & $\begin{array}{l}\text { - Technological } \\
\text { uncertainties; } \\
\text { - Modular } \\
\text { capability; } \\
\text { - Earlier supplier } \\
\text { involvement; } \\
\text { - Integrated and } \\
\text { synchronized } \\
\text { processes }\end{array}$ & \multirow{3}{*}{$\begin{array}{l}\text { - Lead-time } \\
\text { reduction; } \\
\text { - Engineering hours } \\
\text { reduction; } \\
\text { - Costs reduction; } \\
\text { - Quality problems } \\
\text { reduction; }\end{array}$} \\
\hline & $\begin{array}{l}\text { Collaboration in } \\
\text { reference model: } \\
\text { - Collaborative } \\
\text { reference model; }\end{array}$ & \multirow{2}{*}{$\begin{array}{l}\text { - Standardization; } \\
\text { - Clear } \\
\text { communication } \\
\text { between users and } \\
\text { reference model; } \\
\text { - Flexible and } \\
\text { adaptable to } \\
\text { changes; } \\
\text { - Support } \\
\text { development lead } \\
\text { time and quality } \\
\text { improvement; } \\
\text { - World quality } \\
\text { standardization; }\end{array}$} & $\begin{array}{l}\text { - Collaborative and } \\
\text { shared } \\
\text { communication } \\
\text { and information; }\end{array}$ & \\
\hline & $\begin{array}{l}\text { Automotive reference } \\
\text { model: } \\
\text { - Automotive PDP } \\
\text { collaborative } \\
\text { reference model; }\end{array}$ & & $\begin{array}{l}\text { - Common PDP's as } \\
\text { an integration } \\
\text { process; } \\
\text { - Common process } \\
\text { description } \\
\text { allowing } \\
\text { participants to } \\
\text { guarantee } \\
\text { interoperation and } \\
\text { collaborative } \\
\text { processes sharing; } \\
\text { - Common } \\
\text { framework to } \\
\text { manage the } \\
\text { workflow; } \\
\text { - Repository to } \\
\text { register the } \\
\text { processes; }\end{array}$ & \\
\hline
\end{tabular}

\subsection{Taking action}

In this step, the chosen pilot project had the same classification and similar conditions (nomination delayed) as the reference project. The carmaker selected the local supplier with an 8-month delay and the supplier had to freeze the design before the conclusion of the design validation tests. 
After the adjustment of the design process models and definition of the pilot project, work packages were included in (green notes) and excluded from (red notes) the planning and scheduling of the pilot project of the supplier's plan (see Figure 8).

The following work packages were included:

- Carmaker's letter of intent;

- Carmaker's maturity level assessment;

- Carmaker's milestones;

- Kick-off meeting with stakeholders held by carmaker;

- Kick-off meeting with sub-suppliers held by supplier;

- The following work packages were excluded:

- Functional analysis of the product architecture (the product is a derived development);

- Production process gate reviews (the supplier considered the production process separate from the design process);

- (H) Lean manufacturing assessment (there were few adaptations in the final assembly);

- Production process gate reviews (others);

- (J) Supplier's gate review for manufacturing process validation (QS2).

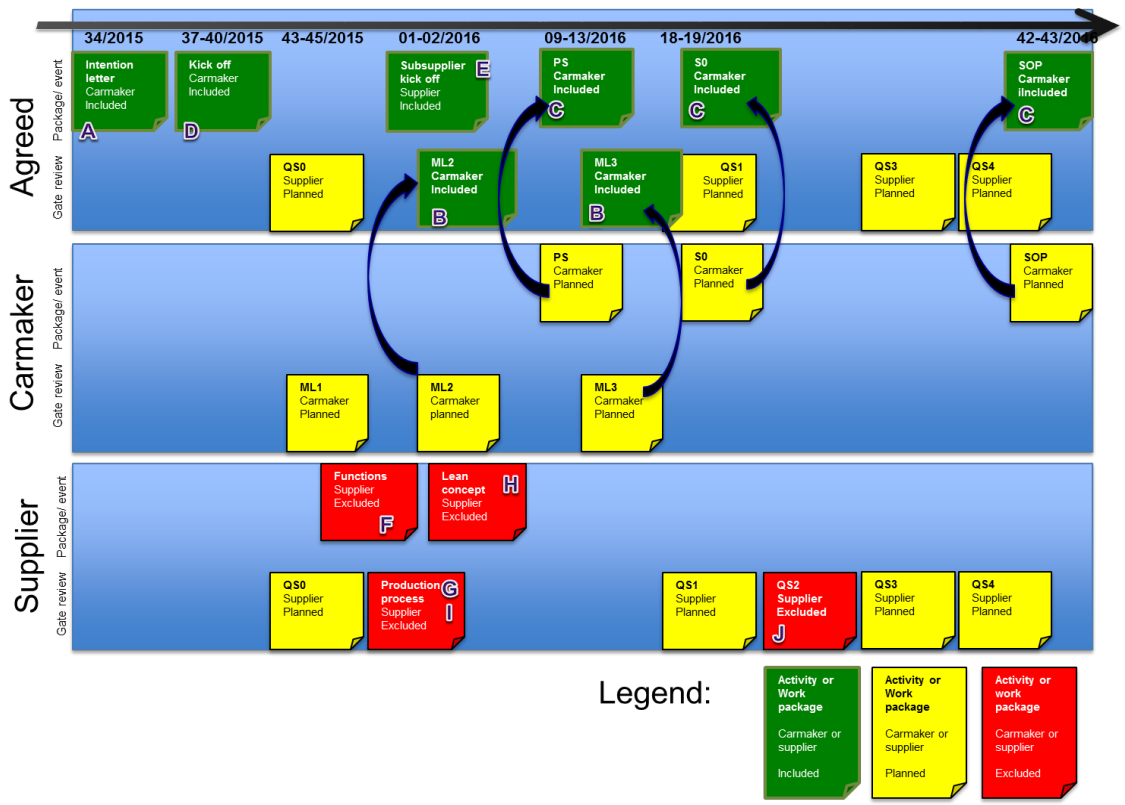

Figure 8. Planned work packages and events for the pilot project. Source: developed by the author.

During the execution of the pilot project, the authors used the project to determine whether the work packages were executed according to the plan, and to identify postponed work packages/activities and unexpected points.

Based on these results, the supplier organization officially announced an additional design process model for this type of project and for this carmaker. However, the supplier's headquarters did not agree to the exclusion of all the gate reviews from the design process model, since many other projects provided no evidence that such an exclusion makes sense. Therefore, although these gates were not executed in either the reference or pilot projects, the gates remained in the new design process model. The customer's events were accepted for inclusion in the new model.

\subsection{Evaluating actions}

The comparison metrics defined in the planning step of this action research were measured. The planned development lead times were totally used up in both projects (reference and pilot); hence, there was no evidence of improvement in lead times.

There was a significant reduction in engineering hours spent on the pilot project. A $38 \%$-time reduction was planned, but a comparison of the actual working hours spent on the pilot versus the reference project was $48 \%$, as can be seen in Figure 9. 


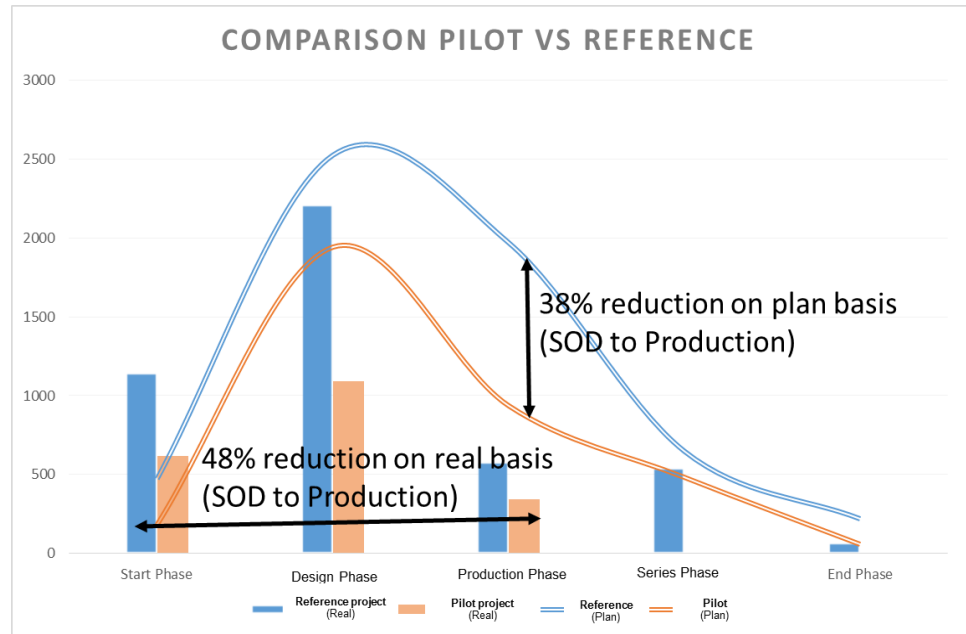

Figure 9. Analysis of engineering hours, comparing pilot and reference projects from start of design (SOD) to production. Source: developed by the author.

The development costs, which are directly related to the reduction of working hours, showed the same trend. In other words, the development costs of the pilot project were almost $50 \%$ lower than the costs of the reference project.

The number of failure claims from the carmaker remained practically the same in both projects.

As discussed earlier, the supplier's design process model aligned to that of carmaker was approved by both the local supplier organization and by its headquarters.

After the customer closed the pilot project, the following statements about the results were made in qualitative interviews:

5. "During the kick-off meeting, the commitment to achieve the milestones of the vehicle project was assertive, flexible and confident. Certain deviations were previously discussed and the definition of problem-solving actions were more reliable." These statements were made by members of both the carmaker and supplier organizations.

6. "Communications with the carmaker were enriched. The integration improved the relationship and the reliability of the information," stated the supplier's project manager.

7. "The customer was really involved in solving the problems. For instance, there was a waiver from the carmaker to the supplier to use some of the design validation results of a previous project to accomplish the events of the vehicle's project." This was stated by both the carmaker and supplier.

\subsection{Reflection cycle (Meta Learning)}

The adjusted work packages created at this customer's collaborative design process model are the basis for development on similar projects (based on NTCP criteria). The scalability of this collaborative design process model must consider the following factors for the next interventions as a condition for creating a set of process models: contractual mode, stage of collaboration, and type of collaboration.

Supplier's capability, tacit knowledge (resources capability), and degree of relationship also raise additional uncertainties and further adjusted work packages, creating different design process models. Therefore, these features should be considered in future actions to create a collaborative process model between first-level suppliers and automakers.

The main contribution to the theory is that key suppliers have to define a set of collaborative process models that are fully integrated to each customer based on a new configuration of the process building blocks. Each process should be based on the customer's point of view. The proposed collaborative process is limited to the B2B relationship between two big players. Existing solutions propose that a supplier may have its own flexible and adaptative process model (Cooper, 2014) but not a process-oriented to the customer product development process.

\section{Conclusions, limitations and opportunities}

When the carmaker's organization involved all of the stakeholders (internally and externally) in the kick-off meeting, the influence of the uncertainty factors decreased, improving the synchronization of data and communication and the accomplishment of the commitment dates.

This improved communication resulted from the integrated and aligned collaborative design process models, which reduced redundant and iterative activities carried out in the reference project, lightening the project team's 
workload. Consequently, the reduction in costs and engineering hours confirmed the effects of collaborative design described in the literature.

The following collaborative characteristics found in the literature were not applied in this action research project: common design process framework and integrated processes between carmaker and supplier; earlier supplier involvement; and the relational contract mode. As the supplier took the initiative, the proposal of this research is from the supplier's standpoint. The supplier created an integrated and aligned collaborative process. The carmaker did not change its process. Probably due to the carmaker's bargaining power, it may not use a common process with its suppliers, as proposed in the literature. A common process could be considered a theoretical and unfeasible initiative.

The results of this research indicate a possibility for first-tier suppliers. They would have a set of collaborative design processes customized for each customer under the same conditions, i.e., same project type according to the NTCP criteria (novelty, technology, complexity, and pace). However, additional applications must corroborate this proposal.

It is evident from the literature and proven by practical cases that the design process model should include all design-related activities, even if they involve other areas. However, it was found that some areas in the supplier organization lack a business process mindset, i.e., they see all the activities for which they are responsible as being part of "their" processes. Therefore, in the supplier organization, some design-related activities were still separate from the backbone of the design process, such as some purchasing activities and manufacturing process activities (such as material planning and scheduling for supporting prototyping construction and evaluation).

One limitation of this work has to do with the methodological approach since only one cycle of the action research was performed. More cases at the same customer should be studied, and studies should extend to other types of projects and other customers to allow additional corroboration of this proposal. There is already an internal initiative to model other design process models to integrate with other customers, but they are not yet in use.

A new research is being planned to build a repository of "customized" design process building blocks to increase the flexibility in defining new design process models tailored for each customer and type of project. This would enable a newly tailored design process to reuse provenly effective building blocks, thus facilitating design management.

\section{Acknowledgements}

The authors thank the Department of Production Engineering of the São Carlos School of Engineering at the University of São Paulo, as well as its associate members who lent us their invaluable support during this research. The authors thanks the supplier organization that participated in this project during the three years of this research.

\section{References}

Amaral, D. C. (2002). Arquitetura para gerenciamento de conhecimentos explícitos sobre o processo de desenvolvimento de produto [Tese de Doutorado]. Escola de Engenharia de São Carlos da Universidade de São Paulo, São Carlos.

Amaral, D. C., Conforto, E. C., Benassi, J. L. G., \& Araujo, C. (2011). Gerenciamento ágil de projetos: aplicação em produtos inovadores (1st ed.). São Paulo: Editora Saraiva.

Amin, S., Mahasan, S. S., \& Khan, F. N. (2014). Impact of collaborative practices on operational performance of firm. Case Study of Automotive Industry of Pakistan., 19(5), 661-668. http://dx.doi.org/10.5829/idosi.mejsr.2014.19.5.13625.

Attia, F. G., \& Rathod, J. (2005). Trends in teaching supplier quality assurance in the global automotive industry. In Proceedings of the 2005 ASEE Gulf-Southwest Annual Conference. Texas: American Society for Engineering Education.

Binder, M. J., Gust, P., \& Clegg, B. T. (2008). The importance of collaborative frontloading in automotive supply networks. Journal of Manufacturing Technology Management, 19(3), 315-331. http://dx.doi.org/10.1108/17410380810853759.

Brones, F. A. (2015). Towards a greater integration of environmental sustainability into product innovation: action research and proposition of an ecodesign transition framework [Tese de Doutorado]. Universidade de São Paulo, São Paulo.

Brown, S. L., \& Eisenhardt, K. M. (1995). Product development: past research, present findings, and future directions. Academy of Management Review, 20(2), 343-378. http://dx.doi.org/10.5465/AMR.1995.9507312922.

Browning, T. R. (2009). The many views of a process: toward a process architecture framework for product development processes Systems Engineering, 12(1), 69-90. http://dx.doi.org/10.1002/sys.

Browning, T. R. (2010). On the alignment of the purposes and views of process models in project management. Journal of Operations Management, 28(4), 316-332. http://dx.doi.org/10.1016/j.jom.2009.11.007.

Browning, T. R., \& Ramasesh, R. V. (2015). Reducing unwelcome surprises in project management. MIT Sloan Management Review, 56(3):53-62.

Camarinha-Matos, L. M., \& Afsarmanesh, H. (2006). Towards a reference model for collaborative networked organizations. IFIP International Federation for Information Processing, 220, 193-202. http://dx.doi.org/10.1007/978-0-387-36594-7 21. 
Choi, Y., Kim, K., \& Kim, C. (2005). A design chain collaboration framework using reference models. International Journal of Advanced Manufacturing Technology, 26(1-2), 183-190. http://dx.doi.org/10.1007/s00170-004-2262-9.

Chrysler Corporation, Ford Motor Company, \& General Motors Corporation. (2008). Advanced product quality planning and control plan (2nd ed.). Southfield: AIAG.

Clark, K. B. (1989). Project scope and project performance: the effect of parts strategy and supplier involvement on product development. Management Science, 35(10), 1247-1263. http://dx.doi.org/10.1287/mnsc.35.10.1247.

Clark, K. B., \& Fujimoto, T. (1989). Lead time in automobile product development explaining the Japanese advantage. Journal of Engineering and Technology Management, 6(1), 25-58. http://dx.doi.org/10.1016/0923-4748(89)90013-1.

Clift, T. B., \& Vandenbosch, M. B. (1999). Project complexity and efforts to reduce product development cycle time. Journal of Business Research, 45(2), 187-198. http://dx.doi.org/10.1016/S0148-2963(97)00227-0.

Coghlan, D. (2007). Insider action research: opportunities and challenges. Management Research News, 30(5), 335-343. http://dx.doi.org/10.1108/01409170710746337.

Conforto, E., Barreto, F., Amaral, D., \& Rebentisch, E. (2015). Modelos híbridos unindo complexidade, agilidade e inovação. Revista Mundo PM, 11(64), 10-17.

Cooper, R. G. (2014). What's next?: after stage-gate. Research Technology Management, 57(1), $20-31$. http://dx.doi.org/10.5437/08956308X5606963.

Coughlan, P., \& Coghlan, D. (2002). Action research for operations management. International Journal of Operations \& Production Management, 22(2), 220-240. http://dx.doi.org/10.1108/01443570210417515.

Coughlan, P., \& Coghlan, D. (2009). Action Research. In C. Karlsson (Ed.), Researching Operations Management (pp. 236-264). New York: Routledge.

Du Preez, N., Lutters, D., \& Nieberding, H. (2009). Tailoring the development process according to the context of the project. CIRP Journal of Manufacturing Science and Technology, 1(3), 191-198. http://dx.doi.org/10.1016/j.cirpj.2008.10.003.

Echeveste, M. E., Amaral, C. S. T., \& Rozenfeld, H. (2007). A support tool for the selection of statistical techniques for industrial product development and improvement processes. In G. Loureiro \& R. Curran (Eds.), Complex systems concurrent engineering (pp 247-255). London: Springer. http://dx.doi.org/10.1007/978-1-84628-976-7_28.

Evans, S., \& Jukes, S. (2000). Improving co-development through process alignment. International Journal of Operations \& Production Management, 20(8), 979-988. http://dx.doi.org/10.1108/01443570010332980.

Gericke, K., \& Moser, H. A. (2012). Adapting a design approach: a case study in a small space company. In P. Heisig \& J. Clarkson (Eds.), Modelling and Management of Engineering Processes - MMEP 2012 (p. 101-114). Cambridge: University of Cambridge.

Guerrini, F. M., \& Pellegrinotti, C. C. (2015). Reference model for collaborative management in the automotive industry. Production Planning and Control, 27(3), 183-197. http://dx.doi.org/10.1080/09537287.2015.1091518.

Guzzo, D. (2016). The uses and users of design process models in organizations [Dissertação de Mestrado]. Escola de Engenharia de São Carlos da Universidade de São Paulo, São Carlos.

Hartley, J., Zirger, B., \& Kamath, R. (1997). Managing the buyer-supplier interface for on-time performance in product development. Journal of Operations Management, 15(1), 57-70. http://dx.doi.org/10.1016/S0272-6963(96)00089-7.

Helfenbein, K. G., \& DeSalle, R. (2005). Falsifications and corroborations: Karl Popper's influence on systematics. Molecular Phylogenetics and Evolution, 35(1), 271-280. http://dx.doi.org/10.1016/j.ympev.2005.01.003.

Highsmith, J. (2012). Gerenciamento ágil de projetos. Rio de Janeiro: Alta Books.

Holian, R., \& Coghlan, D. (2013). Ethical issues and role duality in insider action research: challenges for action research degree programmes. Systemic Practice and Action Research, 26(5), 399-415. http://dx.doi.org/10.1007/s11213-012-9256-6.

Humphrey, J. (2003). Globalization and supply chain networks: the auto industry in Brazil and India. Global Networks, 3(2), 121141. http://dx.doi.org/10.1111/1471-0374.00053.

Kim, C., Lee, J., Kim, K., Lee, J., \& Ryu, K. (2012). A collaborative design framework for the Korean automotive parts industry. International Journal of Computer Integrated Manufacturing, 26(1-2), 3-18. https://doi.org/10.1080/0951192X.2012.681906

Lehmann, F. H., \& Grzegorski, A. (2008). Anlaufmanagement in der nutzfahrzeufindustrie am beispiel Daimler Trucks. In G. Schuh, F. Straube, \& W. Stoelzle (Eds.), Anlaufmanagement in der Automobilindustrie erfolgreich umsetzen (pp. 81-90). Berlin: Springer.

Levardy, V., \& Browning, T. R. (2009). An adaptive process model to support product development project management. IEEE Transactions on Engineering Management, 56(4), 600-620. http://dx.doi.org/10.1109/tem.2009.2033144.

Littler, D., Leverick, F., \& Bruce, M. (1995). Factors affecting the process of collaborative product development: a study of UK manufacturers of information and communications technology products. Journal of Product Innovation Management, 12(1), 16-32. https://doi.org/10.1111/1540-5885.1210016

Martens, B. (2008). Fahrzeuganlaufmanagement bei Volkswagen am Beispiel des VW Tiguan. In G. Schuh (Ed.), Anlaufmanagement in Der Automobilindustrie Erfolgreich Umsetzen (pp. 107-119). Berlin: Springer.

Nakamura, R., Franieck, E. K., Zucco, G. H., Silva, C. G., Nijenhuis, A., \& Rozenfeld, H. (2016). Synergy in the Product Development Process between OEM and Tier-1 Supplier in Brazil. SAE Technical Paper Series, 36-0257. https://doi.org/10.4271/2016-36-0257

Oh, J., \& Rhee, S.K. (2008). The influence of supplier capabilities and technology uncertainty on manufacturer-supplier collaboration: a study of the Korean automotive industry. International Journal of Operations \& Production Management, 28(6), 490-517. https://doi.org/10.1108/01443570810875331 
Oh, J., \& Rhee, S.-K. (2010). Influences of supplier capabilities and collaboration in new car development on competitive advantage of carmakers. Management Decision, 48(5), 756-774. http://dx.doi.org/10.1108/02517471080001503.

Peters, L. D., Johnston, W. J., Pressey, A. D., \& Kendrick, T. (2010). Collaboration and collective learning: networks as learning organisations. Journal of Business and Industrial Marketing, 25(6), 478-484. http://dx.doi.org/10.1108/08858621011066062.

Petersen, K. J., Handfield, R. B., \& Ragatz, G. L. (2005). Supplier integration into new product development: coordinating product, process and supply chain design. Journal of Operations Management, 23(3-4), 371-388. http://dx.doi.org/10.1016/j.jom.2004.07.009.

Petison, P., \& Johri, L. M. (2008). Dynamics of the manufacturer-supplier relationships in emerging markets: a case of Thailand. Asia Pacific Journal of Marketing and Logistics, 20(1), 76-96. http://dx.doi.org/10.1108/13555850810844887.

Ragatz, G. L., Handfield, R. B., \& Scannell, T. V. (1997). Success factors for integrating suppliers into new product development. Journal of Product Innovation Management, 14, 190-202.

Rowley, J. (2003). Action research: an approach to student work based learning. Education + Training, 45(3), 131-138 http://dx.doi.org/10.1108/00400910310470993.

Rozenfeld, H., Forcellini, F. A., Amaral, D. C., Toledo, J. C., Silva, S. L., Alliprandini, D. H., \& Scalice, R. K. (2006). Gestão de desenvolvimento de produtos: uma referência para a melhoria do processo (1. ed.). São Paulo: Editora Saraiva.

Salminen, V., \& Pillai, B. (2005). Integration of products and services - towards system provider and performance partner. In A. Samuel \& W. Lewis (Eds.), International Conference on Engineering Design (pp. 1-15).

Shenhar, A. J., \& Dvir, D. (2007). Reinventing project management: the diamond approach to successful growth and innovation. Boston: Harvard Business School Press.

Shenhar, A. J. (2001). One size does not fit all projects: exploring classical contingency domains. Management Science, 47(3), 394 414. http://dx.doi.org/10.1287/mnsc.47.3.394.9772

Smith, P. G. (2007). Flexible product development: building agility for changing markets (1st ed.). San Francisco: John Wiley \& Sons, Inc. Sommer, A. F., Dukovska-Popovska, I., \& Steger-Jensen, K. (2014). Agile product development governance - on governing the emerging scrum/stage-gate hybrids. In: B. Grabot, B. Vallespir, S. Gomes, A. Bouras \& D. Kiritsis (Eds), Advances in Information and Communication Technology: Vol. 438 (pp. 184-191). Berlin: Springer. http://dx.doi.org/10.1007/978-3-662-44739-0_23.

Sutherland, J. (2014). A arte de fazer o dobro de trabalho na metade do tempo. São Paulo: Leya.

Vanhoucke, M. (2012). Project management with dynamic scheduling: baseline scheduling, risk analysis and project control. The Measurable News, 2, 315. http://dx.doi.org/10.1007/978-3-642-25175-7.

Wu, W. H., Yeh, S. C., \& Fang, L. C. (2007). The development of a collaborative design chain reference model for the motorcycle industry. International Journal of Advanced Manufacturing Technology, 35(3-4), 211-225. http://dx.doi.org/10.1007/s00170-006-0722-0.

Yin, R. K. (2003). Case study research: design and methods. London: Sage.

Zendoia, J., Zapp, M., Agyapong-Kodua, K., Lohse, N., \& Singh, M. (2013). Fundamentals of a co-design methodology for improving the performance of machine tools based on semantic representation. International Journal of Computer Integrated Manufacturing, 26(8), 751-761. http://dx.doi.org/10.1080/0951192X.2013.766936. 